\title{
Learning Effectiveness of Equilibrium Concept of Objects Through the Walking Stability Bipedal Robots
}

\author{
Afrizal Mayub ${ }^{1, *}$ and Fahmizal ${ }^{2}$ \\ ${ }^{I}$ Graduate School of Science Education, University of Bengkulu \\ ${ }^{2}$ Department of Electrical Engineering and Informatics Vocational College, Universitas Gadjah Mada \\ *Corresponding author.Email: afrizalmayub@unib.ac.id
}

\begin{abstract}
This research aims to; (1) Producing a Physics Learning Program Package Based on Center Feedback Simulation Push Bipedal Robot Stability Controller, (2) Describing the effectiveness of Physics Learning using a Physics Learning Program Based on Center Feedback Simulation Simulated Walking Bipedal Robot Stability Controller, (3) Describing the effectiveness level of Learning Physics using the Program Physics Learning Based on Simulation Feedback Center Press Bipedal Robot Stability Controller. The research method is divided into two parts. First, software engineering research is to create a Physics Learning Program Based on the Push Center Feedback Simulation Stability Controller for Bipedal Robot, which includes: Analysis, Design, Code, and Testing. The second is research to see the Physics Learning Program's effectiveness based on the Push Center Feedback Simulation Stability Controller for the Bipedal Robot Walking in learning. Sampling using a total sampling technique. The researchers determined a sample of 40 students of Master of Science in semester 1 and 3 of the 2020/2021 academic year. The results showed that the Physics Learning Program Based on the Push Center Feedback Simulation Stability Controller of the Bipedal Robot was used effectively. It can be seen from the $N_{\text {Gain }}$ value of 0.82 , which is in the high or very effective category. Based on the questionnaire for the Physics Learning Program Based on the Simulation of Press Center Stability Controller of the Bipedal Robot is effective for equilibrium material and the center of mass, it can be seen from the score obtained of 4.14 (from a scale of 1-5) is in the effective category.
\end{abstract}

Keywords: Simulation, Bipedal robot, Equilibrium, Center of mass, Learning Effectiveness.

\section{INTRODUCTION}

Physics is a relatively abstract science, so it is difficult to imagine. As a result, some students solve physics problems with formulas without understanding the philosophical background that underlies it. This causes Physics subjects to be less desirable. Some students have difficulty learning physics [1]. Computers can display abstract physics concepts into reality with static visualization and dynamic visualization (animation). Also, computers can make a concept more attractive, thereby increasing motivation to learn and master it. In line with the above, student learning outcomes for the Physics subject (Magnetic electricity, Mechanics and Environmental Physics) in three learning periods (odd semester 2017/2018, even semester 2017/2018, and odd semester 2018/2019) have not shown optimal results qualitative and quantitative. It is caused by many factors, including still not creating effective learning, the delivery of teaching materials is not attractive, and students are not involved in learning. Learning is less attractive and less effective.

The teaching material presented must follow students' psychological principles to create a pleasant atmosphere and effective learning. Namely arranged in an orderly and systematic manner and equipped with a good multimedia system. The above methods are engineered to meet predetermined quality standards. Computers as a means of e-learning physics allow an interactive multimedia system to be made so that Users can be active, apart from being reactive or passive. Active users here mean a mechanism that allows the user to take the initiative in studying physics, not just being reactive to the prompts given by the computer [1].

The implications of using information technology and computers in making e-learning models generally stem from the learning conditions themselves. The conditions referred to include physics teaching materials, facilities, learning models, students, and teachers who teach. The facts found in the field show that students are less interested in studying physics and find it difficult to understand the material. This is indicated by the low student learning outcomes of physics. Understanding a concept in physics learning is very important, for that animation that can show physical symptoms needs to be prioritized without neglecting other processes.

The Computer Simulation Program can function as a medium for presenting information in the form of text, graphics, simulation, animation, exercises, 
quantitative analysis, direct feedback, active, reactive, individualized instructions according to learning progress, to provide the correct concept to students.

Computer simulation-based physics learning is one of the e-learning applications. E-learning is defined as a form of information technology applied in education in virtual schools [2]. However, in general, the definition of e-learning is learning both formally and informally, which is carried out through electronic media, such as the Internet, Intranet, Extranet, CDROM, videotapes, DVDs, TV, cellphones, PDAs, etc. [3].

In learning, intrinsic motivation should be developed optimally so that student learning effectiveness can be achieved because the motivation comes from within students so that psychologically the driving force is relatively stable and pure. To develop this motivation, E-Learning must present/create a meaningful, thorough, and effective learning process. Students are said to be very effective in learning if the NGain score is $\geq 0.7$ [4]. Besides that, research shows that Virtual Classroom can provide several more attractive options if implemented with the right approach [5].

Virtual learning is in great demand because its potential has been felt to make the learning process effective [6]. Likewise, research at Waseda Japan shows that E-Learning is an effective learning tool. ELearning is significant because the bloom taxonomy provides empirical measurement data to measure the difference between learning using E-Learning and traditional classroom learning. It must be admitted that Bloom's taxonomy can expand the E-Learning learning environment because there are similarities in the privileges and abilities of each individual.[7].

Online classes tend to be successful if based on pedagogical knowledge and the correct preparation of teaching materials [8]. E-learning learning makes students free to learn independently, easily understands abstract and can do practicum virtually [9]. Learning Physics becomes enjoyable for students to consume when it is packaged with good and correct animation [10]. Computers can create meaningful learning, efficient learning management, and effective student administration [11]. Likewise, research on the use of games and 3D animation for learning in junior high schools on the subject of "Building a Space" shows significant differences in learning outcomes between learning using games and 3D animation with conventional learning. Student responses to games and $3 \mathrm{D}$ animation in learning are more than $70 \%$ or classified as high [12]. Development of physics learning with multiple representations based on ICT could increase mastery of kinematics concepts, good perceptions, and good motivation [13]. Physics learning program based on computer simulation must be able to "concrete" abstract concepts so that it is easy for students to understand. This can be realized with computers' help. Specifically, the study in this study is the Effectiveness of Learning the Concept of Equilibrium of Objects and the Center of Mass through the Simulation of the Press Center Feedback Stability Controller of the Walking Bipedal Robot.

Based on the description above, the problem is formulated as follows "How to implement a central feedback simulation program for the bipedal robot stability controller running to make learning effective in the concept of an object and center balance," so that the objectives of this study are (1) Producing a Physics Learning Program Package Based on Computer Simulation, (2) describe the effectiveness of learning physics using a computer simulation based physics learning program, (3) describe the effectiveness level of learning physics using a computer simulation based physics learning program.

\section{RESEARCH METHODS}

This type of research consists of software engineering research and educational research. Software engineering research conducted in direct experimental research aims to simulate the center of pressure (CoP) using a Foot Pad Sensor and Controlling the Bipedal Robot's Walking Stability. After software engineering research, then educational research continued. Pressure Center Simulation (CoP) using Foot Pad Sensor and Controlling Walking Stability Bipedal Robot is used as a medium and teaching material in equilibrium and center of mass learning to streamline student learning. Educational research was carried out at the Postgraduate Science Faculty FKIP UNIB Bengkulu. In contrast, software engineering research was carried out at the UGM Vocational School Yogyakarta and at the S2 FKIP UNIB Bengkulu Science from May to September 2020.

\section{Materials and Tools}

The tools used in this simulation consist of a robot, a computer device, a flat table, sloping with a flat floor and steps, and the MatLab software.

\section{Research Stage}

In various situations, the robot is directly connected to a computer that has loaded a simulation program written using Matlab software. Furthermore, various robot maneuvers are carried out so that a change in the pressure point is seen on the monitor screen when there is a change in pressure on the robot. The concept of equilibrium is done by moving the robot to run in various field conditions (Figure 1). 


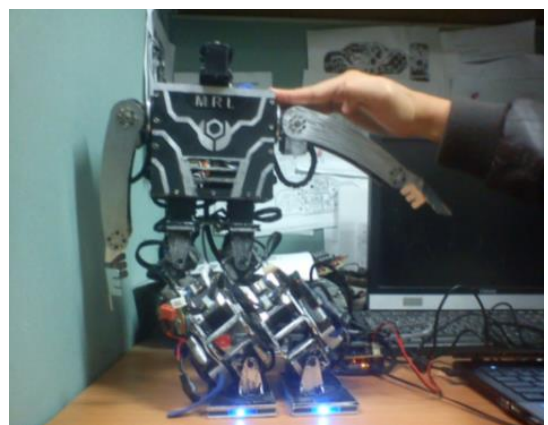

Figure 1. Bipedal Robots

\section{Bipedal Robots Simulation Characteristics}

Simulation is a way of duplicating or describing the features, appearance, and characteristics of a real system [14]. This method moves a real situation to the study room because of the difficulty of practicing in real situations [15].

a. Center of mass

The center of mass is a point on an object that contains the mass of all the particles. This makes up the object considered to be centered at that point (Figure 2).

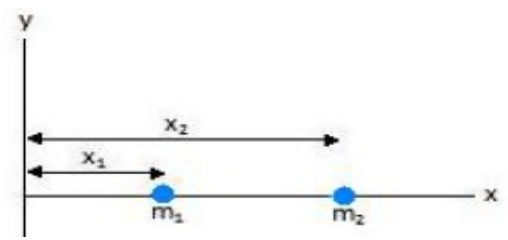

Figure 2. Finding the center of mass

$\mathrm{m} 1=$ mass of particle $1, \mathrm{~m} 2=$ mass of particle 2 . Both particles are on the $\mathrm{x}$-axis. Particle 1 is $\mathrm{x} 1$ from the $\mathrm{y}$ axis, and particle two is $\mathrm{x} 2$ from the $\mathrm{y}$ axis. The center of mass is abbreviated as PM. The two particles are located on the $\mathrm{x}$-axis, so the center of mass of the two particles is written as XPM.

$$
x P M=\frac{\left(m_{1} x_{1}+m_{2} x_{2}\right)}{\left(m_{1}+m_{2}\right)}
$$

$\mathrm{m}=\mathrm{m} 1+\mathrm{m} 2=$ total mass of the two particles. The center of mass lies between the two particles. [16].

\section{b. Equilibrium}

Requirements necessary and sufficient for the balance of an analytically rigid object must meet the requirements; total directional force $\mathrm{x}=0\left(\sum \mathrm{Fx}=0\right)$, total directional force $\mathrm{y}=0\left(\sum \mathrm{Fy}=0\right)$, and number of moments $=0\left(\sum \mathrm{M}=0\right)$ [17]. From this equation, it can be said that objects do not move in the translation direction or the direction of rotation (rest). See the following illustration;

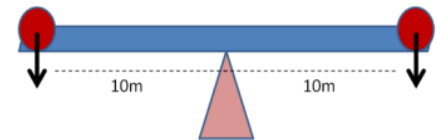

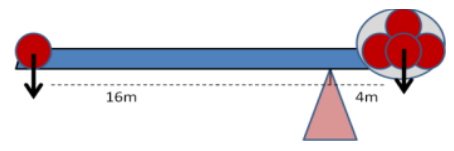

Figure 3. Determining the balance of objects $m_{1} x_{1}=m_{2} x_{2} \rightarrow 1 \times 10=1 \times 10$ dan $m_{1} x_{1}=$ $m_{2} x_{2} \rightarrow 1 \times 16=4 \times 4$

c. Determine the center of pressure (CoP) using the Foot Pad Sensor

The Center of Pressure, CoP for short, is the point on the SP (Support Polygon) of the two-legged robot with the total contact force of the FR acting

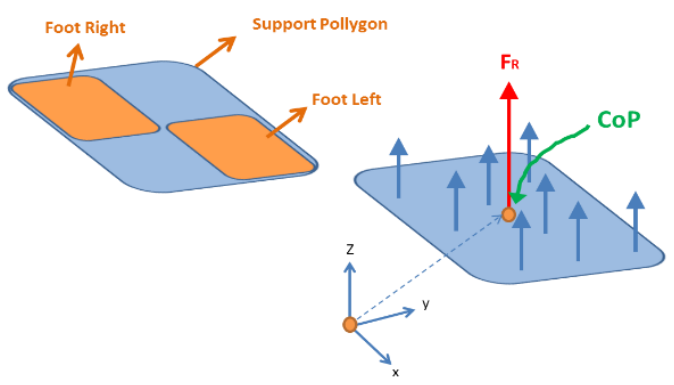

CoP

Figure 4. Determining the Press Center (CoP) of the Walking Bipedal Robot [18].

Positioning the CoP on the Single Support Leg

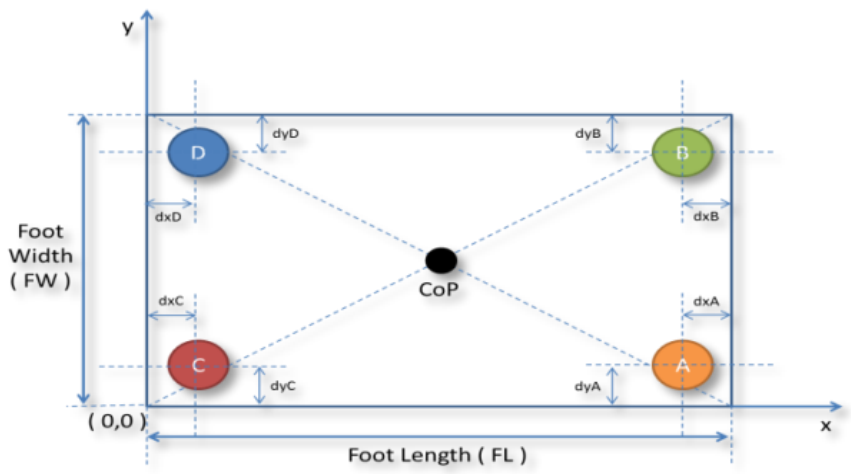

Figure 5. Positioning the CoP on the Single Support Leg [18].

$X C_{0} P=\frac{f_{A} X P_{A}+f_{B} X P_{B}+f_{C} X P_{C}+f_{D} X P_{D}}{f_{A}+f_{B} \mathrm{~B}+f_{C}+f_{D}}$

$Y C_{0} P=\frac{f_{A} Y P_{A}+f_{B} Y P_{B}+f_{C} Y P_{C}+f_{D} Y P_{D}}{f_{A}+f_{B}+f_{C}+f_{D}}$

$X P_{A}=F L-d x A \quad X P_{A}=F W-d y A$

$X P_{B}=F L-d x B \quad Y P_{B}=d y B$

$X P_{C}=d x C \quad Y P_{C}=F W-d y C$

$X P_{D}=d x D \quad Y P_{D}=d y D$

The forces on the legs are $f A, f B, f C$, and $f D$ 


\section{d. Implementation in Education}

Implementation in educational research, the Simulation of the Press Center Feedback Stability Controller for the Walking Bipedal Robot is used as a medium and material. The concept of equilibrium of matter and center of mass. The research design is presented in Table 2.1.

\begin{tabular}{lll}
\multicolumn{3}{c}{ Table 2.1 Research Design } \\
\hline Pre-test & Perlakuan & Post-test \\
\hline $\mathrm{O}_{1}$ & $\mathrm{X}$ & $\mathrm{O}_{2}$ \\
\hline
\end{tabular}

$\mathrm{X}$ : Center Feedback Simulation Learning Press Bipedal Robot Stability Controller, O1: Initial test (pre-test), O2: Final Test (post-test)

The research subjects used 40 students of Master of Science in semester 1 and 3 of the 2020/2021 academic year

1) Data Collection.

The test questions have given the aim to determine the effectiveness of using Computer Simulation-Based Physics Learning Programs in Physics Learning. The test questions are adjusted to the desired competencies in learning. This study used 30 items. The Computer Simulation-Based Physics Learning Program Questionnaire was distributed to all samples to be studied, and each sample/research subject was required to provide a qualitative and quantitative assessment through a questionnaire regarding the function of the Computer SimulationBased Physics Learning Program to make student learning more effective. The questionnaire totaled 40 statements. In each statement, there were five choices with the following conditions;[19]

Table 2.2 Selection criteria and scores on the questionnaire

\begin{tabular}{clcc}
\hline No & \multicolumn{1}{c}{ Option } & Score & Category \\
\hline 1 & Strongly agree & 5 & $\mathrm{~A}$ \\
2 & Agree & 4 & $\mathrm{~B}$ \\
3 & I quite agree & 3 & $\mathrm{C}$ \\
4 & Disagree & 2 & $\mathrm{D}$ \\
5 & Strongly disagree & 1 & $\mathrm{E}$ \\
\hline
\end{tabular}

\section{2) Processing data}

Student learning outcomes data consists of the results of the pre-test and post-test, then processed with a formula,

$$
N_{\text {gain }}=\frac{\left(X_{2}-X_{1}\right)}{\left(X_{3}-X_{1}\right)} \text { [20]. }
$$

Magnitude $\mathrm{x} 1=$ pretest score, $\mathrm{x} 2=$ posttest score and $\mathrm{x} 3=$ maximum score. Questionnaire data to determine the effectiveness of learning using the following criteria

Table 2.3 Criteria for the effectiveness of Computer Simulation-based Physics Learning

\begin{tabular}{llll}
\hline 1 & 5 & A & Very good \\
2 & 4 & B & Good \\
3 & 3 & C & Midle \\
4 & 2 & D & Less \\
5 & 1 & E & Bad \\
\hline
\end{tabular}

3) Data analysis.

Computer Simulation-Based Physics Learning Program used to test the effectiveness of learning. Manual calculations were used, namely, N-Gain's effectiveness formula as follows. $\mathrm{N}-$ Gain $=$ post-test score - initial ability test score maximum score Initial Ability Test score [21][22]. N-Gain = Normalized gain Pre-test $=$ Initial learning value Post-test $=$ Final learning value. The Computer Simulation-Based Physics Learning Program is said to be effective in learning physics if the student's post-test results are greater than the pre-test results $(\mathrm{X} 2>\mathrm{X} 1)$ and the number of students who score $\geq 70$ $\geq 80 \%$. Meanwhile, the Ngain formula is used to determine the level of effectiveness of physics learning. The comparison between the post-test and the pre-test values is formulated as follows

$$
N_{\text {gain }}=\frac{\left(X_{2}-X_{1}\right)}{\left(X_{3}-X_{1}\right)}
$$

The quantities $\mathrm{X}_{1}, \mathrm{X}_{2}$, and $\mathrm{X} 3$ are as pre-test scores, post-test scores and maximum scores. Ngain numbers range from 0 to 1 to determine the level of effectiveness of using the ICT-Based Physics Learning Program. used the following criteria

Table 2.4 Gain Index Criteria

\begin{tabular}{llrl}
\hline & Effectiveness Level & \multicolumn{1}{c}{$\mathrm{N}_{\text {gain }}$} & Category \\
\hline 1 & Very effective & $\geq 0,70$ & Hight \\
2 & effective & $0,30-0,70$ & Midle \\
3 & Effective enough & $\leq 0,30$ & Low \\
\hline
\end{tabular}

Computer Simulation-based Physics Learning Program to determine learning effectiveness is also obtained through a commissioner with the following criteria.

Table 2.5 Criteria for the effectiveness of Computer Simulation-based Physics Learning

\begin{tabular}{llcl}
\hline No & Criteria & Category & Quality \\
\hline 1 & $4,50-5,00$ & A & Very effective \\
2 & $3,51-4,50$ & B & effective \\
3 & $2,51-3,50$ & C & Less effective \\
4 & $1,51-2,50$ & D & Ineffective \\
5 & $<1,5$ & E & Very ineffective \\
\hline
\end{tabular}

The score obtained is then processed by SPSS.

\section{RESULTS AND DISCUSSION}

Matlab Simulation - CoP Position during SSP (Single Support Phase) Foot

Matlab Simulation - CoP Position during SSP (Single Support Phase)

Foot Force through foot $\mathrm{fA}=255 ; \mathrm{fB}=255 ; \mathrm{fC}=255$; and $\mathrm{fD}=255$; 


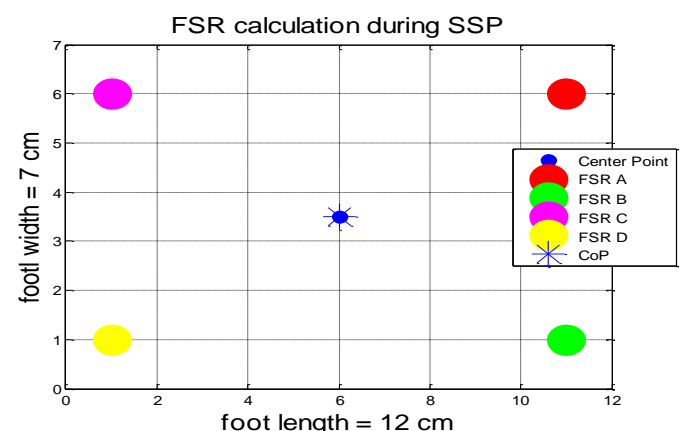

Figure 6. Matlab Simulation - CoP Position during SSP Force through foot $\mathrm{fA}=30 ; \mathrm{fB}=10 ; \mathrm{fC}=50$; and $\mathrm{fD}=230$;

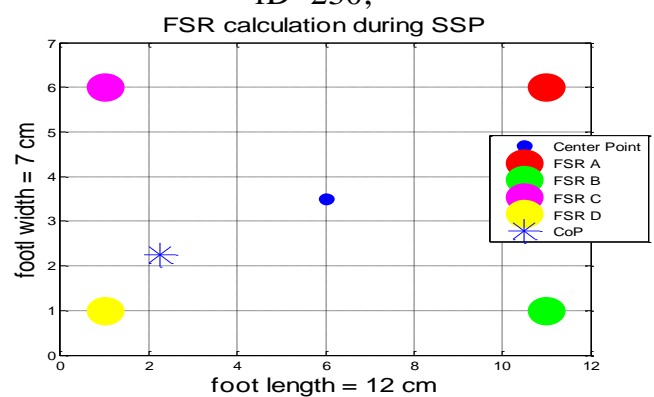

Figure 7. Matlab Simulation - CoP Position during SSP-1

Matlab Simulation - CoP Position during DSP (Double Support Phase) Foot

Force through foot LEFT: $\mathrm{fA} 1=255 ; \mathrm{fB} 1=255 ; \mathrm{fC} 1=255$; and $\mathrm{fD} 1=255$

Force through foot RIGHT: $\mathrm{fA} 2=255$; $\mathrm{fB} 2=255 ; \mathrm{fC} 2=255$; andfD2 $=255$

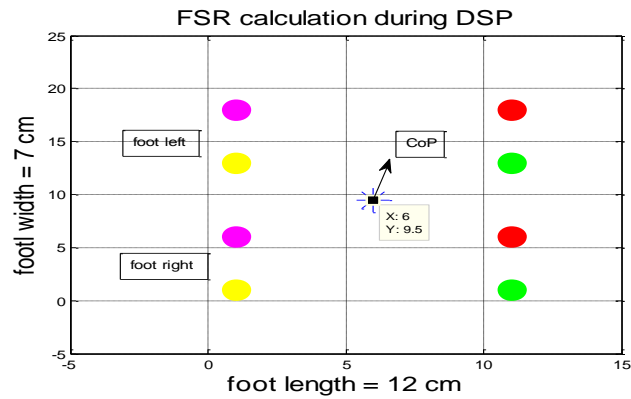

Figure 8. Matlab Simulation - CoP Position during DSP-1

Force through foot LEFT: $\mathrm{fA} 1=20 ; \mathrm{fB} 1=56 ; \mathrm{fC} 1=70$; and $\mathrm{fD} 1=43$;

Force through foot RIGHT:

$\mathrm{fA} 2=234 ; \mathrm{fB} 2=189 ; \mathrm{fC} 2=218 ; \mathrm{fD} 2=255$;

Displacement $=3 \mathrm{~cm}$

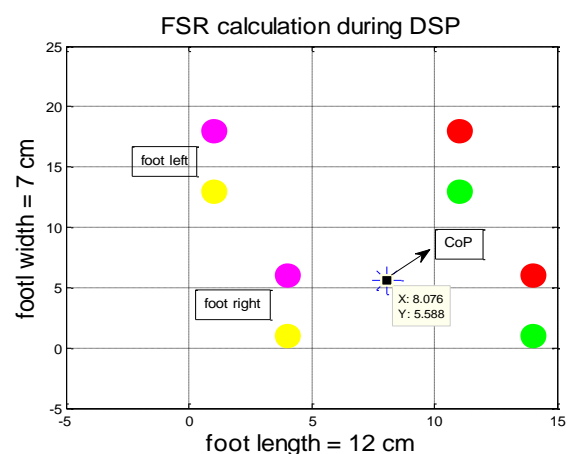

Figure 9. Matlab Simulation - CoP Position during DSP-2

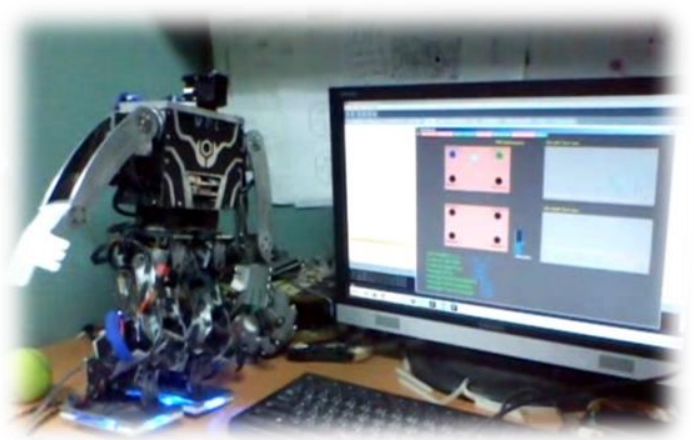

Figure 10. Image of Robot Equilibrium Test when given interference from the side

\section{Implementation in Education}

The implementation of this research was carried out at S2 IPA FKIP UNIB Bengkulu and at the Department of Electronics and Computers at Vocational School UGM Yogyakarta, in 2020. This study aims to determine the effectiveness of learning the concept of object balance and mass center through a center feedback simulation for controlling the stability of the walking bipedal robot. To determine the effectiveness of the learning, a pre-test and post test were carried out. The pre-test aims to determine students' initial understanding of the Equilibrium and Mass Center material before learning. The post-test aims to determine the students' understanding of the Equilibrium and Mass Center material after receiving treatment in the form of learning using the Feedback Simulation Center Press Stability Controller for the Bipedal Robot Walking. There are 30 multiple choice questions in the pre-test and post-test questions. The results of the pre-test and post-test can be seen in Figure 11 and table 3.1. 


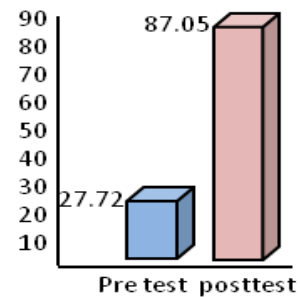

Figure 11. Graph of pretest and posttest

Based on table 3.1, the NGain size can be calculated using a formula

$$
N_{\text {Gain }}=\frac{(87.05-27.72)}{(100-27.72)}=\frac{(59,33)}{(72,38)}=0,82
$$

while the standard deviation is calculated using a formula

$$
s=\sqrt{\frac{\sum_{i=1}^{n}\left(x_{i}-\bar{x}\right)^{2}}{n-1}}
$$

Magnitude $\mathrm{s}=$ standard deviation, $\mathrm{xi}=$ ith value, $\mathrm{x}=$ average score and $\mathrm{n}=$ sample size. Based on calculations using SPSS, the average score of the questionnaire/learning effectiveness was 4.14. Meanwhile, the standard deviation of post-test learning outcomes is 4.2904; the standard deviation of the questionnaire/learning effectiveness is 0.398 . The results showed that the Learning Center Feedback Simulation Learning Program of the Bipedal Robot Stability Controller was used effectively. It can be seen from the $N_{\text {Gain }}$ value of 0.82 , which is in the high or very effective category. When using the questionnaire result indicator, the score is 4.14 in the effective category

Table 3.1 Recapitulation of pretest, posttest, and

\begin{tabular}{|c|c|c|c|c|}
\hline No & $\left(x_{i}-x\right)^{2}$ & pretest & Posttest & Questionnaire \\
\hline 1 & 0.25 & 27 & 87 & 4.6 \\
\hline 2 & 99.0 & 27 & 77 & 4.3 \\
\hline 3 & 8.7 & 23 & 90 & 4.5 \\
\hline 4 & 8.7 & 37 & 90 & 4.2 \\
\hline 5 & 8.7 & 30 & 90 & 4.4 \\
\hline 6 & 8.7 & 30 & 90 & 4.4 \\
\hline 7 & 8.7 & 27 & 90 & 3.4 \\
\hline 8 & 0.25 & 27 & 87 & 3.8 \\
\hline 9 & 8.7 & 23 & 90 & 3.9 \\
\hline 10 & 49.7 & 27 & 80 & 4.5 \\
\hline 11 & 0.25 & 27 & 87 & 4.2 \\
\hline 12 & 99.6 & 23 & 77 & 4.4 \\
\hline 13 & 8.7 & 37 & 90 & 3.8 \\
\hline 14 & 8.7 & 30 & 90 & 3.9 \\
\hline 15 & 8.7 & 30 & 90 & 4.5 \\
\hline 16 & 8.7 & 20 & 90 & 3.5 \\
\hline 17 & 8.7 & 20 & 90 & 3.3 \\
\hline 18 & 16.4 & 33 & 83 & 4.6 \\
\hline 19 & 16.4 & 30 & 83 & 4.3 \\
\hline 20 & 8.7 & 37 & 90 & 4.5 \\
\hline
\end{tabular}
questionnaire scores

\begin{tabular}{ccccc}
21 & 8.7 & 30 & 90 & 4.2 \\
22 & 49,7 & 30 & 80 & 4.4 \\
23 & 8.7 & 20 & 90 & 4.4 \\
24 & 8.7 & 20 & 90 & 3.4 \\
25 & 0.25 & 33 & 87 & 3.8 \\
26 & 0.25 & 30 & 87 & 3.9 \\
27 & 0.25 & 13 & 87 & 4.5 \\
28 & 8.7 & 17 & 90 & 4.2 \\
29 & 49.7 & 27 & 80 & 4.4 \\
30 & 0.25 & 40 & 87 & 3.8 \\
31 & 99.0 & 17 & 77 & 3.9 \\
32 & 8.7 & 30 & 90 & 4.5 \\
33 & 8.7 & 43 & 90 & 3.5 \\
34 & 8.7 & 20 & 90 & 3.3 \\
35 & 8.7 & 27 & 90 & 4.6 \\
36 & 8.7 & 27 & 90 & 4.3 \\
37 & 16.4 & 23 & 83 & 4.5 \\
38 & 16.4 & 37 & 83 & 4.2 \\
39 & 8.7 & 30 & 90 & 4.4 \\
40 & 8.7 & 30 & 90 & 4.4 \\
$\sum$ & 664.45 & 1109 & 3482 & 165.6 \\
Average & 27.725 & 87.05 & 4.14 \\
STDEV & 6.5632 & 4.2904 & 0.398 \\
\hline
\end{tabular}

Learning becomes effective and very effective using a Physics Learning Program Based on the Press Center Feedback Simulation Stability Controller for the Bipedal Robot Walking is caused by an interactive multimedia system so that almost all senses are involved in absorbing and constructing knowledge. Learning using the Physics Learning Program Based on the Feedback Simulation Center Press the Bipedal Robot Stability Controller allows students to learn freely, can be done anytime and anywhere, and is equipped with animations and simulations would enable students to be motivated in learning.

The convenience and ease of use of using the Physics Learning Program Based on the Feedback Simulation Center Press, the Bipedal Robot Stability Controller could help students feel at home in learning. This pleasant atmosphere increases the enthusiasm of students to learn. The display presented by the Physics Learning Program Based on the Center for Press Feedback Simulation Stability Controller of the Bipedal Robot allows all types of student intelligence to be accommodated to grow and develop optimally. Almost all student intelligence can be contained and manifested in an e-learning program based on the Push Center Feedback Simulation Walking Bipedal Robot Stability Controller. However, the e-learning learning program based on the Push Center Feedback Simulation Stability Controller for the Walking Bipedal Robot, could not be assigned explicitly to a certain type of intelligence. It is one type of program that can accommodate various kinds of intelligence because there are no clear boundaries 
about a person's type of intelligence. A person may have several types of intelligence, but not all intelligence types are prominent in that person, but only a part of it, and for each person, the type of intelligence that stands out is not the same. In general, it can be said that the Learning Center Feedback Simulation program for the Bipedal Robot Stability Controller for equilibrium and center of mass material can be done relatively easily, efficiently, effectively, individually, and cheaply.

The display was presented with the Physics Learning Program Based on the Press Center Feedback Simulation Stability Controller of the Bipedal Robot. It was equipped with animation, simulation, visualization, demo, and analysis module as a training module that allows student misconceptions to reduce physics' misconceptions. This is due to the effort to "concrete" things that have been considered abstract by students. This finding is in line with other findings that use e-learning in learning in various countries.

European research has also found that distance and open learning models containing Howard Gardner's multiple intelligences are a medium for disseminating education and act as a means to achieve new levels of understanding and awareness and reflect the role of education [24]. Research in South Africa found that to optimize student potential. Learning is carried out based on multiple intelligences [25]. This finding is also in line with other studies that say that multiple intelligences impact e-learning activities that are rigorous for the integration of various intelligence with an e-learning model [26]. All intelligence types can grow and develop optimally in the learning process when applied and supported by e-Learning programs [27].

The findings above are also in line with previous findings, through a questionnaire by 45 respondents showing that the project requirements that use the Product-Service System (PSS) model to determine the overall Virtual Classroom development roadmap are going well and feasible to be implemented [28]. Furthermore, research on the use of Interactive 3D ELearning at SMP No.151 and MTs No.77B/95 Bandung shows that Interactive 3D E-Learning is liked and very liked $(S+S S)$ to be used as a learning medium $74 \%$. Also increasing cognitive abilities 83 $\%$, interesting and easy to use $77 \%$, motivating and attracting interest in learning 78\% [20]. The research findings above indicate the existence of a learning format in cyber (e-learning) via computers and the internet [30]. Student learning activities and achievements in the web-based real analysis course in the form of e-learning increased, and student learning completeness was achieved by $92.5 \%$ [31].

E-learning effectiveness score as planning
(77.57\%), material creation (75.14\%), material delivery $(66.14 \%)$, interaction $(75 \%$,$) , evaluation$ $(69.01 \%$,$) , and media learning by 77.27 \%$ [32]. JPTE PT UNM students are motivated to learn Electrical Installation 2, which uses Adobe Flash CS3 animation in the good category (75\%) [33]. Biology learning uses multiple intelligence-based e-learning in human motion systems, showing learning outcomes increases by $21 \%$, and learning completeness reaches $100 \%$ so that the student learning process becomes effective [34]. As an interactive learning media based on Information Technology, E-learning shows that manifested in a module containing teacher content that includes questions, announcements, uploading teaching materials, checking, and announcing test results. Content students include viewing announcements, exam results, and downloading teaching materials [35]. The e-learning system to improve the teaching and learning process at SMA N 10 Bandar Lampung, the study results decided to build an e-learning Learning Management System using ANP analysis [36].

The development of E-learning-based Online Learning Methods in the Computer Engineering Programming course of IPB Bogor shows that the Development of E-learning-Based Learning Methods can be carried out properly. It is supported by network facilities and infrastructure and the socialization of these methods to the academic community in the Directorate of IPB Diploma Program [37]. Intelligent e-learning with personalization used data mining techniques. The decision support system at elearningujb.net concludes; Data mining techniques and decision-making systems can be used in recommending teaching materials, books, course materials, journals that match the interests of users of the elearning-ujb.net site [38]. E-learning Moodle is feasible to use the eligibility based on the experts in the good category of 3.98. According to media experts, it is categorized as good with a score of 3.98 . Based on the beta test, including the very good category with a score of 4.15 , product testing is in the good category score of 3.90 and effectively improve student learning outcomes by 13.24 [39]. E-learning assisted by the virtual laboratory is valid for use, as evidenced by experts' score for material aspects of $91.67 \%$, media aspects of $96.75 \%$. The score for student questionnaires for online practicum was $81.30 \%$, for the small group stage was $81.50 \%$, and the virtual laboratory was efficient to use [40].

Application of Blended Learning with Numbered Heads Together (NHT) increased interest and learning achievement in solubility material and solubility product at SMA N Gondangrejo. This study shows that; Student interest increased from $73.37 \%$ to $78.93 \%$, mastery learning increased from $50.00 \%$ to 
$79.17 \%$, while psychomotor was $79.17 \%$. [41]. Other findings show that e-learning programs in learning can motivate students to learn [42]. 2015). The use of elearning programs in learning can play a good role [43]. The use of e-learning programs in learning can significantly reduce student misconceptions [44]. 2017). The use of the e-learning program in learning can be a place for developing multiple intelligences [45].

\section{CONCLUSION}

Physics Learning Program Based on Simulation Feedback Center Press Bipedal Robot Stability Controller Running used effectively in learning material equilibrium and center of mass. it can be seen from the $\mathrm{N}_{\text {Gain }}$ value of 0.82 , which is in the high or very effective category. Based on the questionnaire, this program was also effectively used for equilibrium material, and the center of mass it can be seen from the score obtained of 4.14 (from a scale of 1-5) is in the effective category.

\section{ACKNOWLEDGMENTS}

The implementation of this research was based on the assistance of various parties. Therefore, the researchers would like to express their deepest gratitude to the Dean of FKIP Bengkulu University for providing funds so that this research collaboration can be carried out optimally. We also thank the UGM Vocational School Computer and Electronics Laboratory for collaborating on this research so that the research can run smoothly.

\section{REFERENCES}

[1] Sutrisno. Fisika Komputasi dan Kurikulum Inti Pendidikan Sarjana Fisika dan Sarjana Pendidikan Fisika, 1993.

[2] Purbo O.W., Hartanto, A.A. Teknologi eLearning, PT Elex Media Komputindo, Jakarta, 2001.

[3] Team E-learning. Buku Panduan WebCT 4.1 Untuk Pengajar, Universiteit Utrecht dan Universitas Padjadjaran, Bandung, 2004.

[4] Sugiyono Metode Penelitian Kombinasi (Mix Methods). Bandung: Alfabeta, 2015.

[5] Marie, Georgianna, Virtual Classroom Instruction: Strategies for Keeping Participants Engaged, Diakses February 2010 from http://www. $\quad$ gmariegroup.com/VILTWorkshop/ASTD_TK_20, 2009

[6] Haryono. Virtual Learning/Virtual Classroom, Sebagai model pendidikan jarak jauh: Konsep dan penerapannya, Seminar Nasional Teknologi Pembelajaran, Balai Besar Pengembangan Teknologi Tepat Guna-LIPI, 2012.
[7] Laela HalawiBelajar Efektif Dengan E-Learning Faculty of Human Sciences, Waseda University and Faculty of Education, Nagasaki University, Japan, 2010

[8] Nawaz Allah, Using e-learning as a tool for 'education for all' in developing states, Depart of Public Administration, Gomal University, Deha Ismail Khan, KPK Pakistan, 2011.

[9] Mustadji. Pemanfaatan Multimedia Untuk Meningkatkan kualitas Pendidikan, seminar AKAL interaktif di TB., Gramedia EXSPO Surabaya, 2011.

[10] DePorter and HernackiDifferences in Learning Method Using Quantum Learning Flash Animation with Conventional Learning On The Concept of Temperature and Heat, Google Translate for Business: Translator Toolkit Website Translator Global Market Finder., 2011

[11] Morten Brekke, Peter Henrik Hosted. New Teaching Method-Using computer technology in physics, mathematics and computer science, International Journal of Digital Society, Volume 1, issue 1, March, p.19, 2010

[12] Yandri, Disain, Implementasi dan Pengujian Efektivitas Interactive E-Learning Menggunakan Game dan Animasi 3D, Sekolah Teknik Elektro dan Informtika, ITB, Bandung, 2009,.

[13] Ishafit. Pengembangan Pembelajaran fisika dengan multiple Representations Berbasis ICT untuk meningkatkan Penguasan Konsep Kinematika, Persepesi, dan motivasi Mahasiswa PGMIPA-BI, Prosideding Pertemuan Ilmiah XXVIII HFI Jateng \& DIY, Yogyakarta, April 2014.ISSN 0853-0823, 2014.

[14] Mayub, A.. Pembuatan Program Pembelajaran Berbantuan Komputer, Unit Penerbitan dan Publikasi FKIP UNIB, 2019

[15] Othman, Ahmad Nizam bin Film Animasi Malaysia: Narasi Verbal ke Visual, ITB J. Vis. Art \& Des., Vol. 3, No. 1, 2009, 79-88 79, 2009 ,

[16] Joni Rokhmat, M.Si. Fisika Dasar Pendekatan Berpikir Kausalitik, Penerbit Arga Puji Press Mataram Lombok. Web site: www.argapuji.com, 2017.

[17] Halliday, D., Resnick, R., Walter, J. Fundamentals of Physics, by Jhon Willey \& Soon Inc. 1997

[18] Mayub A, Fahmizal. Center of Pressure Feedback for Controlling the Walking Stability Bipedal Robots using Fuzzy Logic Controller, International Journal of Electrical and Computer Engineering (IJECE), 2018.

[19] Mahmud. Metode Penelitian Pendidikan. Bandung: CV Pustaka Setia, 2011.

[20] Arikunto, S. 2010. Prosedur Penelitian Suatu Pendekatan Praktik. Jakarta: Rineka Cipta. 
[21] Sugiyono. Metode Penelitian Kuantitatif, Kualitatif, dan $R \& D$. Bandung: Alfabeta, CV, 2017

[22] Sutama.. "Metode Penelitian Pendidikan". Surakarta: Fairuz Media, 2011.

[23] Sugiyono. Metode Penelitian Kuantitatif, Kualitatif dan R\&D. Bandung: PT Alfabe, 2016.

[24] Medeiros Vieira, Leandro, and Ferasso, Marcos and Schröeder, Christine, Connecting Multiple Intelligences through Open and Distance Learning: Going towards a Collective Intelligence? European Journal of Open, Distance and E-Learning, Volume 17, Issue 1, Jul 2014. Available at SSRN: https://ssrn.com/ abstract $=2875482,2014$

[25] FE Gouws. Journal Teaching and learning through multiple intelligences in the outcomesbased education classroom, Africa Education Review, Volume 4, 2008.

[26] Kunjal Bharatkumar Mankad. The Role of Multiple Intelligence in E-Learning, IJSRD International Journal for Scientific Research \& Development| Vol. 3, Issue 05, 2015 | ISSN (online): 2321-0613, 2015.

[27] Christopher Pappas. Multiple Intelligences In eLearning: The Theory And Its Impact, elearning industry, 2005.

[28] Risnandar. Perancangan e-learning dengan Pendekatan Product-Service System (PSS) dan DICE Framework, Konferensi dan Temu Nasional Teknologi Informasi dan Komunikasi untuk Indonesia, Bandung, 2010.

[29] Sianipar DB,. Desain dan Pengembangan Interactive 3 Dalam Meningkatkan Kemampuan Kognitif Siswa, Laporan Penelitian, Magister Teknik Elektro ITB, Bandung, . 2010.

[30] Sehat Sempurna Perkembanagn e-learning, Jur.Teknik Komputer dan jaringan ITBSEOMOLEC, Bandung, 2012.

[31] Dian Kurniati, Dinawati Trapsilasiwi. Pengembangan model Pembelajaran analisis real berbasis web dalam bentuk e-learning; (C)Kadikma, Vol.5, No.3, hal 1-12, 2014.

[32] Numiek SH. Keefektivitas e-learning sebagai media pembelajaran di SMK Telkom Sandhy Putra Purwokerto, Jurnal Pendidikan Vokasi Vol.3 No.1 Februari 20013, 2013.

[33] Hasrul, Desain Media Pembelajaran Animasi berbasis Adobe Flash CS3 pada mata kuliah intalasi listrik 2, Jurnal Medtek, Vol.3 No.2 Oktober, 2011.

[34] Isni Murdiyani, Pembelajaran Biologi menggunakan elearning berbasis multiple intelligences pada system gerak manusis, Journal of Curriculum and Educational, Vo.1, No.1, 2012, ISSN 2252-7125. 2012.
[35] M. Yazdi. E-learning sebagai media pembelajaran interaktif berbasis Teknologi Informasi, Jurnal Ilmiah Foristek Vol.2, No.1, Maret 2012, 2012.

[36] Novi Hidayati. Sistem e-learning untuk meningkatkan proses belajar-mengajar pada SMA N 10 Bandar Lampung, Jurnal Telematika Mkom Vol.2, No.2, 2010.

[37] Budi, Brian Nurjayanti. Pengembangan Metode Pembelajaran Online Berbasis E-learning pada mata kuliah Pemrograman Teknik Komputer IPB Bogor, Jurnal Sains Terapan Edisi II Vol.2 No.1 Hal 103-113, 2012.

[38] Agus S.A. E-elarning cerdas dengan personalisasi menggunakan teknik data mining dan decision support system pada elearningujb.net Univ.Janabadra,Ykt, Seminar Nasional Informatika 2010, Yogyakarta 2010; ISSN 19792328, 2010.

[39] Zyainuri, Eko Marpanaji. Penerapan elearning moodle untuk pembelajaran siswa yang melaksanakan Prakerin, Jurnal Pendidikan Vokasi, Vol.2 No.3, 2012.

[40] Dwi Agustine, Ketang Wiyono, M.Muslim. Pengembangan elearning berbantuan virtual laboratory untuk mata kuliah praktikum fisika dasar II di program studi pendidikan fisika FKIP UNSRI, Jurnal Inovasi dan Pembelajaran Fisika Vol.1 No.1, 2014

[41] Jatmiko BP, J.S Sukarjo, Sri Mulyani, Penerapan Blended Learning dengan Numbered Heads Together (NHT) untuk meningkatkan minat dan prestasi belajar pada materi kelarutan dan hasil kali kelarutan di SMA N Gondangrejo, 2013, Jurnal Pendidikan Kimia Vol.2 No.4 Thn 2013, ISSN 2337-9995, 2013.

[42] Mayub, Implementasi Virtual Classroom Sebagai Upaya Memotivasi Mahasiswa Belajar Fisika, Laporan Penelitian, 2015.

[43] Mayub, Analisis peran e-learning dalam pembelajaran Fisika Dasar Laporan Penelitian , 2016.

[44] Mayub, Rekayasa Model Program E-learning Sebagai Wadah Perbaikan Miskonsepsi Fisika Pada Mahasiswa, Laporan Penelitian, 2017

[45] Mayub, Menumbuhkembangkan Inteligensi Ganda melalui Program E-learning Berbasiskan ICT, Laporan Penelitian, 2018. 